\title{
A CO Sensor Consisted of Ion Plated Au Film and Neutral Buffer Solution
}

\author{
Syoichi UCHIKOSHI*, Toru ISHIJI, Shuzi FUKUDA ${ }^{\dagger}$ \\ and Koji TACHIBANA ${ }^{\dagger}$
}

Received February 1, 1993 ; Accepted March 19, 1993

\section{INTRODUCTION}

A toxic $\infty$ gas has been detected in working environments such as chemical plants and steel making for a long timel). So, many electrochemical $\mathrm{C} 0$ sensors consisted of a platinum black working electrode and $\mathrm{H}_{2} \mathrm{SO}_{4}$ solution have been widely used to detect the $\mathrm{C} 0$ gas $^{2-5)}$. The sensor of this type, however, is hard to handle, because it includes a strong acid and oxide layer may be formed on the electrode to lower its catalytic activity.

In this study, we attempted to make a co sensor which consisted of a thin layer gold electrode and a neutral buffer solution, and its performance was investigated.

\section{EXPERIMENTAL}

A schematic of the 00 gas sensor made by us is shown in Figure 1. This Au working electrode was formed on a gas permeable Teflon membrane(PTFE) by ion plating method. The Au plating was carried out under following conditions; substrate bias voltage of $-0.5 \mathrm{kV}, \mathrm{RF}$-power of $600 \mathrm{~W}$ and $\mathrm{Ar}$ gas atmosphere of $1.3 \times 10^{-2 \mathrm{~Pa}}$. The platinum black printed on the PTFE was served as the counter electrode. The reference electrode is a $\mathrm{Ag} / \mathrm{AgCl}$ (saturated $\mathrm{KCl}$ ). Three kinds of buffer solution, $\mathrm{pH} 3\left[\mathrm{C}_{6} \mathrm{H}_{4}(\mathrm{COOK})(\mathrm{COOH})+\right.$ $\left.\mathrm{HNO}_{3}\right]$, pH7 $\left[\mathrm{KH}_{2} \mathrm{PO}_{4}+\mathrm{Na}_{2} \mathrm{~B}_{4} \mathrm{O}_{7}\right]$ and $\mathrm{pH} 11\left[\mathrm{Na}_{2} \mathrm{HPO}_{4}+\mathrm{NaOH}\right]$, were prepared as the electrolyte. $\mathrm{C} 0$ with a flow rate of $0.2 \mathrm{dm}^{3} / \mathrm{min}$ diluted with $\mathrm{N}_{2}$ or pure AIR was fed to the sensor to evaluate the

Riken Keiki Co. Ltd., Azusawa 2-7-6, Itabashiku, Tokyo 174, Japan.

$\dagger$ Dep. of Chem., Sci. Univ. of Tokyo, Kagurazaka 1-3, Shinjuku-ku, Tokyo 162, Japan.

Key words: gas sensor, carbon monoxide, amperometric detection, Au film electrode.

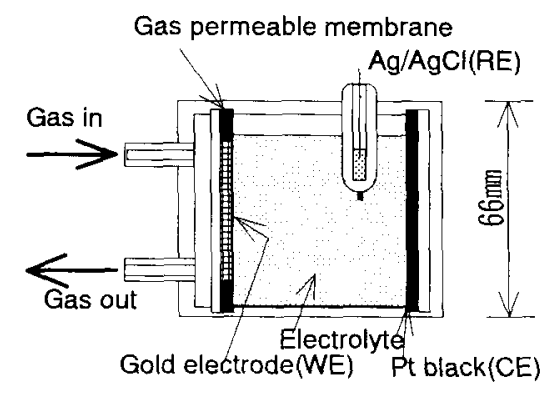

Fig. 1 Schematic of a $\mathrm{CO}$ sensor.

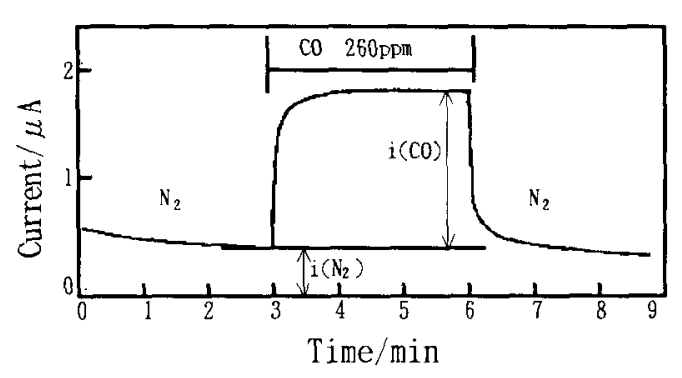

Fig. 2 Response of a CO sensor with a solution of $\mathrm{pH} 7$ at $+0.3 \mathrm{~V}$ vs. $\mathrm{Ag} / \mathrm{AgCl}$ (sat. $\mathrm{KCl}$ ). 00 concentration was $260 \mathrm{ppm}$ ( $\mathrm{N}_{2}$-balance).

functional characteristic. The potential of the working electrode was controlled by a conventional potentiostat. All measurements were carried out at $25 \pm 0.5^{\circ} \mathrm{C}$.

\section{RESUTS AND DISCUSSION}

First, the current response of the sensor was investigated under various potentials by feeding an inert $\operatorname{gas}\left(\mathrm{N}_{2}\right)$ and a diluted $\mathrm{CO}$ gas $\left(\mathrm{CO}+\mathrm{N}_{2}\right)$ in turn, to determine the most suitable constant potential which gives a stable and re- 

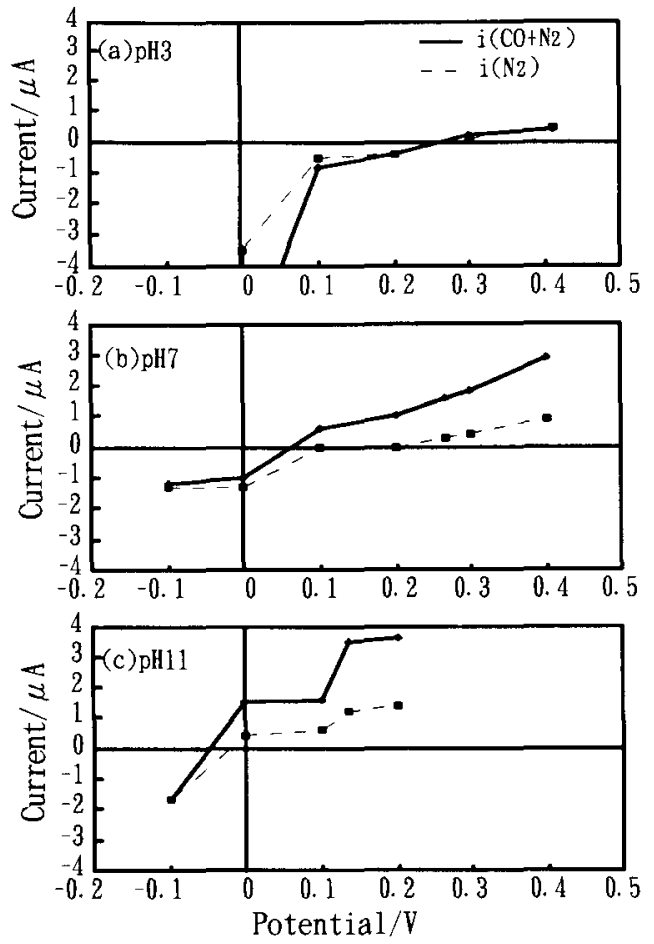

Fig. 3 Dependence of $\mathrm{i}\left(\mathrm{N}_{2}\right)$ and $\mathrm{i}\left(\mathrm{CO}+\mathrm{N}_{2}\right)$ on the electrode potential using each $\mathrm{pH}$ solution. $\mathrm{CO}$ concentration was $260 \mathrm{ppm}$.

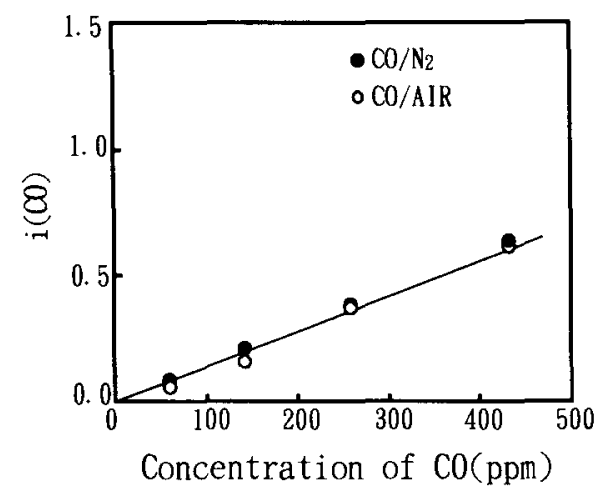

Fig. 4 Relationship between $C 0$ concentration and $i(\mathrm{CO})$ at $+0.3 \mathrm{~V}$ vs. $\mathrm{Ag} / \mathrm{AgCl}$ (sat. $\mathrm{KCl}$ ) solution of pH7.

producible current for electrochemical oxidation of $\infty$. Figure 2 is an example of the current re $^{-}$ sponse obtained at $+0.3 \mathrm{~V}$ ( $\mathrm{vs} . \mathrm{Ag} / \mathrm{AgCl}$ ) in a buffer solution of pH7. It is found from Fig. 2 to be excellent in the response, that is, the background current under $\mathrm{N}_{2}$ flow is also reproduced before and after $\mathrm{CO}$ feeding along with the sharp increase and decrease of current. In Fig. 2, the current corresponding to $\mathrm{CO}$ concentration, $\mathrm{i}(\mathrm{CO})$, is the value which subtracted the background current $\mathrm{i}\left(\mathrm{N}_{2}\right)$ from $\mathrm{i}\left(\mathrm{CO}+\mathrm{N}_{2}\right)$.

Figure 3 shows dependence of $\mathrm{i}\left(\mathrm{N}_{2}\right)$ and $i\left(\mathrm{CO}+\mathrm{N}_{2}\right)$ on electrode potential in different buffered $\mathrm{pH}$ solutions. It is desirable for the sensor that the background current is small and the current susceptible to $\mathrm{C} 0$ is large. It can be seen from Fig. 3 that there is no difference between $i\left(\mathrm{~N}_{2}\right)$ and $\mathrm{i}\left(\mathrm{CO}+\mathrm{N}_{2}\right)$ over whole potential range in the pH3 solution, and the background current is too large in the pH11 solution. In the buffer solution of pH7, it was found that there was significant difference between $\mathrm{i}\left(\mathrm{N}_{2}\right)$ and $\mathrm{i}\left(\mathrm{CO}+\mathrm{N}_{2}\right)$ as well as the smaller background current. Therefore, we chose the potential value of $+0.3 \mathrm{~V}$ as the setting potential of the sensor, along with adopting the solution of $\mathrm{pH} 7$.

0ther two kinds of buffer solutions of pH3 and 7 prepared by mixing $\mathrm{Na}_{2} \mathrm{HPO}_{4}$ and citric acid were also compared with the performance in above mentioned solutions ( $\mathrm{pH} 3$ and 7 ). There was no essential difference so far as adopting $\mathrm{pH} 7$, even in the solution containing citric acid.

Using such conditions in the $\mathrm{pH}$ and the potential, dependence of $i(C)$ on the $C 0$ concentration was investigated, as shown in Fig. 4. The output current $\mathrm{i}(\mathrm{CO})$ was found to have a good linearity to the $C 0$ concentration over the wide range, independent of the kinds of the dilution gas. It could be considered that the newly developed $C 0$ gas sensor working at $+0.3 \mathrm{~V}$ in the buffer solution of $\mathrm{pH} 7$ was promising to detect quantitatively the $\mathrm{CO}$ gas in various working environments.

\section{REFERENCES}

1) ACGIH: "Threshold Limit Values for Chemical Substances and Biological Exposure Indices" 1991-92(1991).

2) H. W. Bay, K. F. Blurton, J. M. Sedlak and

A. M. Valentine, Ana1. Chem , 46, 122, (1974).

3) K. F. Blurton and J. M. Sedlak, J. Electrochem. Soc., $121,10(1974)$.

4) J. M. Sedlak and K. F. Blurton, J. Electrochem. Soc, 123, 10(1976).

5) H. Ki ta, H. Nakajima and K. Hayashi, J. Electroana1. Chem , 190, 141(1985). 